\title{
KONSEP UTANG DALAM AKAD PEMBIAYAAN MUDHARABAH PADA BANK SYARIAH
}

\author{
Oleh \\ Trisadini Prasastinah Usanti \\ Fakultas Hukum Universitas Airlangga \\ Email : aditris@ymail.com
}

\begin{abstract}
Abstrac
Mudharabah is a financing method in which two parties - a sharia bank (shahibul maal) which provides the capital, and a customer (mudharib) who supplies the labor and skill to manage the funds-are involved in a contractual relationship. The profit shared by them has to be mutually consented upon and explicitly stated at the time of contracting. However, it is the sharia bank that is accountable in case of loss if it is not caused by the customer, considering the fact that the customer has spared his time and energy. Similarly, it is the customer that is liable for the loss if it is caused by the customer himself. In fact, mudharabah has not been purely practiced for it still involves the term debt in the contract.
\end{abstract}

Keywords: Debt, Mudharabah, Sharia Bank

\begin{abstract}
Abstrak
Pembiayaan Mudharabah adalah pembiayaan dalam bentuk kerja sama antara bank syariah sebagai shahibul maal yang menyediakan seluruh modal dan nasabah sebagai mudharib yang mengelola dana. Keuntungan usaha sesuai dengan kesepakatan yang dituangkan dalam akad. akan tetapi apabila terjadi kerugian maka akan ditanggung oleh bank syariah apabila kerugian tersebut bukan karena kesengajaan dari nasabah, sedangkan nasabah rugi waktu, tenaga dan pikiran. Apabila kerugian disebabkan oleh kelalaian dari nasabah maka nasabah harus menanggung kerugian tersebut. Akan tetapi, pada pembiayaan mudharabah pada salah satu bank syariah belum menunjukkan karakter dari pembiayaan mudharabah secara utuh karena muncul konsep utang dalam akadnya.
\end{abstract}

Kata kunci: utang, mudharabah, bank syariah

\section{PENDAHULUAN}

Bank syariah mempunyai karakteristik yang berbeda dengan bank konvensional, yaitu disamping berfungsi sebagai intermediasi juga berfungsi sosial sebagaimana diamanatkan pada pada Pasal 4 Undang-Undang Nomor 21 Tahun 2008 tentang Perbankan Syariah (selanjutnya disebut Undang-Undang Perbankan Syariah). Secara garis besar kegiatan operasional bank syariah dibagi 
menjadi 3 (tiga) kategori, yaitu kegiatan penghimpunan dana (funding), kegiatan penyaluran dana (lending) dan jasa bank berupa penyediaan bank garansi (kafalah), letter of credit (L/C), hiwalah, wakalah dan jual beli valuta asing (sharf).

Bank syariah menghimpun dana dari masyarakat dalam bentuk simpanan ${ }^{1}$ dan investasi ${ }^{2}$, dan menyalurkan kembali dana tersebut kepada masyarakat yang memerlukannya dalam bentuk pembiayaan. Menurut Pasal 1 angka 12 UndangUndang Nomor 7 Tahun 1992 tentang Perbankan sebagaimana telah diubah dengan Undang-Undang Nomor 10 Tahun 1998 (selanjutnya disebut UndangUndang Perbankan) yang dimaksud pembiayaan berdasarkan prinsip syariah adalah penyediaan uang atau tagihan yang dipersamakan dengan itu berdasarkan kesepakatan antara bank dengan pihak lain yang mewajibkan pihak yang dibiayai untuk mengembalikan uang atau tagihan tersebut setelah jangka waktu tertentu dengan imbalan atau bagi hasil. Sedangkan Pembiayaan menurut Pasal 1 angka 25 Undang-Undang Perbankan Syariah adalah penyediaan dana atau tagihan yang dipersamakan dengan itu berupa transaksi bagi hasil dalam bentuk Mudharabah dan Musyarakah, transaksi sewa-menyewa dalam bentuk ijarah atau sewabeli dalam bentuk ijarah muntahiyah bit tamlik, transaksi jual beli dalam bentuk piutang Murabahah, Salam dan Istishna, transaksi pinjam meminjam dalam bentuk piutang Qardh dan transaksi sewa menyewa jasa dalam bentuk Ijarah untuk transaksi multijasa. Berdasarkan persetujuan atau kesepakatan antara bank syariah dan/atau UUS dan pihak lain yang mewajibkan pihak yang dibiayai dan/atau diberi fasilitas dana untuk mengembalikan dana tersebut setelah jangka waktu tertentu dengan imbalan ujrah, tanpa imbalan atau bagi hasil.

\footnotetext{
${ }^{1}$ Pasal 1 angka 20 Undang-Undang Perbankan Syariah yang dimaksud dengan Simpanan adalah dana yang dipercayakan oleh Nasabah kepada Bank Syariah dan/atau UUS berdasarkan Akad wadi'ah atau Akad lain yang tidak bertentangan dengan Prinsip Syariah dalam bentuk Giro, Tabungan, atau bentuk lainnya yang dipersamakan dengan itu

${ }^{2}$ Pasal 1 angka 24 Undang-Undang Perbankan Syariah yang dimaksud dengan Investasi adalah dana yang dipercayakan oleh Nasabah kepada Bank Syariah dan/atau UUS berdasarkan Akad mudharabah atau Akad lain yang tidak bertentangan dengan Prinsip Syariah dalam bentuk Deposito, Tabungan, atau bentuk lainnya yang dipersamakan dengan itu
} 
Salah satu pembiayaan yang disalurkan oleh bank syariah adalah pembiayaan Mudharabah. Mudharabah menurut Abdullah Saeed adalah sebuah perjanjian diantara paling sedikit dua pihak, yaitu satu pihak pemilik modal (shahib al-mal atau rabb al-mal) mempercayakan sejumlah dana kepada pihak lain, pengusaha (mudharib), untuk menjalankan suatu aktivitas atau usaha. ${ }^{3}$ Muhammad Syafii Antonio mendefinisikan, Al mudharabah adalah akad kerjasama antara dua pihak dimana pihak pertama (shahibul maal) menyediakan seluruh modal, sedangkan pihak lain (mudharib) menjadi pengelola, keuntungan usaha dibagi dalam bentuk prosentase (nisbah) sesuai kesepakatan, sedangkan apabila rugi ditanggung oleh pemilik modal selama kerugian itu bukan akibat kelalaian si pengelola, seandainya kerugian itu diakibatkan oleh kelalaian si pengelola maka si pengelola harus bertanggung jawab atas kerugian tersebut. ${ }^{4}$

Dalam bahasa penduduk Irak dinamakan Mudharabah sedangkan penduduk Hijaz menyebutnya Qiradh..$^{5}$ Qiradh berasal dari kata Al Qardhu yang berarti Al Qath'u artinya pemilik memotong sebagian hartanya untuk diperdagangkan untuk mendapatkan keuntungan, atau berasal dari kata $A l$ Muqaradhah yang artinya Al Musaawah (persamaan) atau karena modal dari si pemilik modal dan pekerjaan hanya dituntut untuk bekerja saja maka ia sama seperti mengambil upah (ijarah); maka si pekerja mempunyai hak untuk mendapatkan bagian dari keuntungan. ${ }^{6} \quad$ Landasan syariah al-mudharabah secara umum lebih mencerminkan anjuran untuk melakukan usaha. Hal ini nampak dalam ayat-ayat Al Qur'an dan hadits berikut ini: Dalam surat Al Muzzammil ayat 20: “... dan dari orang-orang yang berjalan di muka bumi mencari sebagian karunia Allah SWT....". demikian juga disinggung dalam Surat Al Jumu'ah ayat 10: “Apabila telah ditunaikan shalat maka bertebaranlah kamu di muka bumi dan

\footnotetext{
${ }^{3}$ Abdullah Saeed, Islamic Banking and Interest a Study of The Prohibition of riba and Contemporery Intrepretation, (New York-Koln: E.J Briil Leiden,1996), hal.66

${ }^{4}$ Muhammad Syafii Antonio, Bank Syariah : Suatu Pengenalan Umum, (Jakarta:Tazkia Institute, 2000), hal. 135

${ }^{5}$ Tim Couterpart Bank Muamalat, Fiqh Muamalah Perbankan Syariah, hasil terjemahan dari Buku Al Fiqh Aal Islam wa Adillatuhu, karya Wahbah Zuhaili, (Jakarta, 1999), hal.140

${ }^{6}$ Ibid
} 
carilah karunia Allah SWT...." demikian juga dalam Surat Al Baqarah ayat 198: “Tidak ada dosa (halangan) bagi kamu untuk mencari karunia Tuhanmu....". Dalam Al-Hadits yang diriwayatkan dari Ibnu Abbas bahwa Sayyidina Abbas Bin Abdul Muthalib jika memberikan dana ke mitra usahanya secara mudharabah ia mensyaratkan agar dananya tidak dibawa mengarungi lautan, menuruni lembah yang berbahaya, atau membeli ternak. Jika menyalahi aturan tersebut, yang bersangkutan bertanggung jawab atas dana tersebut. Disampaikanlah syarat tersebut pada Rasulullah SAW dan beliau membolehkannya.. (H.R.Thabrani). Dalam hadits yang lain yaitu dari Shalih bin Shuhaib r.a. bahwa Rasulullah SAW bersabda, "Tiga hal yang didalamnya terdapat keberkatan: jual beli secara tangguh, muqaradhah (mudharabah), dan mencampur gandum dengan tepung untuk keperluan rumah, bukan untuk dijual”. (H.R.Ibnu Majah No.2280, kitab At Tijarah). ${ }^{7}$ Mudharabah dibedakan dalam 2 (dua) bentuk, yaitu:

1. Mudharabah Muthlaqah. Mudharabah muthalaqah adalah bentuk kerjasama antara shahibul maal dan mudharib yang cakupannya sangat luas dan tidak dibatasi oleh spesifikasi jenis usaha, waktu dan daerah bisnis. Dalam pembahasan fiqh ulama Salaf Ash Shalih seringkali dicontohkan dengan ungkapan if'al ma syi'ta (lakukanlah sesukamu) dari shahibul maal ke mudharib yang memberi kekuasaan sangat besar.

2. Mudharabah Muqayyadah, sedang dalam mudharabah muqayyadah (restricted mudharabah/spesified mudharabah), mudharib dibatasi dengan batasan jenis usaha, waktu atau tempat usaha. ${ }^{8}$

Dalam praktik bank syariah akad mudharabah dipergunakan untuk membingkai hubungan hukum antara bank syariah dengan nasabah investor pada penghimpunan dana dalam bentuk tabungan dan deposito dan juga dipergunakan untuk membingkai hubungan hukum antara bank syariah dengan nasabah penerima fasilitas dalam penyaluran dana, yaitu pembiayaan mudharabah, akan tetapi bentuk mudharabah pada investasi dengan pembiayaan berbeda. Pada

\footnotetext{
${ }^{7}$ Sutan Remy Sjahdeini, Perbankan Islam dan Kedudukannya dalam Tata Hukum Perbankan Indonesia, (Jakarta: Pustaka Utama Grafiti, 1999), hal.135.

${ }^{8}$ Muhammad Syafii Antonio, Op.Cit., hal.127.
} 
umumnya bentuk mudharabah yang dipergunakan pada investasi adalah mudharabah mutlaqah sedangkan pada pembiayaan mudharabah yang dipergunakan adalah bentuk mudharabah muqayyadah. Hal ini dikarenakan nasabah investor mempercayakan dananya pada bank syariah untuk dikelola yang cakupannya sangat luas dan tidak dibatasi oleh oleh spesifikasi jenis usaha, waktu dan daerah bisnis, sehingga bank syariah dapat leluasa untuk mengelola dana tersebut. Sedangkan untuk pembiayaan, bank syariah menetapkan batasan jenis usaha, waktu dan daerah bisnis. Hal ini sebagai upaya bank syariah untuk melindungi kepentingan nasabah penyimpan dana, nasabah investor dan sebagai penerapan dari prinsip kehati-hatian. ${ }^{9}$ Uraian tersebut di atas dapat digambarkan dalam tabel sebagai berikut:

\section{Tabel 1. Penerapan akad mudharabah pada produk bank syariah}

\begin{tabular}{|c|c|}
\hline Pada Tabungan dan Deposito & Pada Pembiayaan \\
\hline $\begin{array}{l}\text { Pada umumnya berlaku akad } \\
\text { mudharabah Muthlaqah, yaitu bentuk } \\
\text { kerjasama antara shahibul maal } \\
\text { (nasabah penyimpan/nasabah investor) } \\
\text { dan mudharib (bank syariah) yang } \\
\text { cakupannya sangat luas dan tidak } \\
\text { dibatasi oleh spesifikasi jenis usaha, } \\
\text { waktu dan daerah bisnis, meskipun ada } \\
\text { akad mudharabah muqayyadah yang } \\
\text { melandasi penerbitan deposito, yaitu } \\
\text { bank syariah bertindak sebagai agen } \\
\text { penyalur dana investor (channelling } \\
\text { agent) kepada nasabah yang bertindak } \\
\text { sebagai pengelola dana untuk kegiatan } \\
\text { usaha dengan persyaratan dan jenis } \\
\text { kegiatan usaha yang ditentukan oleh } \\
\text { nasabah investor. }\end{array}$ & $\begin{array}{l}\text { Berlaku akad mudharabah } \\
\text { muqayyadah, yaitu bentuk kerja sama } \\
\text { antara shahibul maal (bank syariah) } \\
\text { dan mudharib (nasabah } \\
\text { penyimpan/nasabah investor) yang } \\
\text { cakupannya dibatasi oleh spesifikasi } \\
\text { jenis usaha, waktu dan daerah bisnis. }\end{array}$ \\
\hline
\end{tabular}

Berdasarkan statistik perbankan syariah baik bank umum syariah dan unit usaha syariah di Indonesia dalam periode Januari 2013 pembiayaan mudharabah sebesar 12.027 milyard dan musyarakah sebesar 28.092 milyard jauh lebih kecil

\footnotetext{
${ }^{9}$ Yahman dan Trisadini Prasastinah Usanti, Bunga Rampai Hukum Aktual Dalam Prespektif Hukum Bisnis Kontraktual Berimplikasi Pidana dan Perdata, (Surabaya: Mitra Mandiri,2011), hal.63
} 
dibandingkan dengan pembiayaan murabahah sebesar 89.665 milyard. ${ }^{10}$ Hal ini disebabkan pembiayaan berdasarkan jual beli khususnya murabahah merupakan pembiayaan yang mudah untuk diaplikasikan oleh bank syariah, mengingat tingkat keuntungan yang akan diterima oleh bank syariah sudah pasti. Akad ini dikenal dengan natural certainty contract, yaitu akad dalam bisnis yang memiliki kepastian keuntungan baik dalam segi jumlah dan waktunya. sedangkan pada pembiayaan mudharabah dan musyarakah tingkat keuntungan yang tidak pasti dan dibutuhkan perhitungan yang detail dalam menentukan pembagian keuntungan berdasarkan nisbah bagi hasil antara bank syariah dengan nasabah. Di samping itu adanya risiko moral hazard dari mudharib (pengelola dana). Akad ini dikenal dengan natural uncertainty contract. ${ }^{11}$

\section{PEMBAHASAN}

Berdasarkan Peraturan Bank Indonesia Nomor 12/13/PBI/2011 tentang Penilaian Kualitas Aktiva Bagi Bank Umum Syariah dan Unit Usaha Syariah pada Pasall angka 5 disebutkan bahwa Pembiayaan berdasarkan akad mudharabah, yang selanjutnya disebut Pembiayaan Mudharabah, adalah Pembiayaan dalam bentuk kerja sama suatu usaha antara bank yang menyediakan seluruh modal dan nasabah yang bertindak selaku pengelola dana dengan membagi keuntungan usaha sesuai dengan kesepakatan yang dituangkan dalam akad, sedangkan kerugian ditanggung sepenuhnya oleh bank kecuali jika nasabah melakukan kesalahan yang disengaja, lalai atau menyalahi perjanjian.

Sebagaimana juga diatur pada Pasal 6 Peraturan Bank Indonesia Nomor 7/46/PBI/2005 tentang Akad penghimpunan Dana dan Penyaluran Dana Bagi

${ }^{10}$ Data pembiayaan yang diberikan (PYD) dari data statistik Perbankan Syariah yang dikeluarkan oleh Bank Indonesia. [www.bi.go.id], diakses pada tanggal 20 Oktober 2013

11 Trisadini Prasastinah Usanti,et.al., “ Prinsip Keadilan dalam Transaksi Berdasarkan Bagi Hasil di Bank Syariah”, Penelitian dibiayai oleh DIPA BOPTN Tahun Anggaran 2013 sesuai dengan Surat Keputusan Rektor Universitas Airlangga Tentang Kegiatan Penelitian Unggulan Perguruan Tinggi Nomor:8714/UN3/KR/2013 Tanggal 25 Juni 2013, hal. 42. Lihat juga Sunarto Zulkifli, Panduan Praktis Transaksi Perbankan Syariah, ( Jakarta:Zikrul Hakim, 2003), hal.16 
Bank Yang Melaksanakan Kegiatan Usaha Berdasarkan Prinsip Syariah jo. Peraturan Bank Indonesia Nomor Peraturan Bank Indonesia Nomor 9/19/PBI/2007 tentang Pelaksanaan Prinsip Syariah Dalam Kegiatan Penghimpunan Dana dan Penyaluran Dana serta pelayanan Jasa Bank Syariah, bahwa dalam kegiatan penyaluran dana dalam bentuk pembiayaan berdasarkan Mudharabah berlaku persyaratan paling kurang sebagai berikut:

a. Bank bertindak sebagai shahibul maal yang menyediakan dana secara penuh, dan nasabah bertindak sebagai mudharib yang mengelola dana dalam kegiatan usaha;

b. jangka waktu pembiayaan, pengembalian dana, dan pembagian keuntungan ditentukan berdasarkan kesepakatan Bank dan nasabah;

c. Bank tidak ikut serta dalam pengelolaan usaha nasabah tetapi memiliki hak dalam pengawasan dan pembinaan usaha nasabah;

d. pembiayaan diberikan dalam bentuk tunai dan/atau barang;

e. dalam hal pembiayaan diberikan dalam bentuk tunai harus dinyatakan jumlahnya;

f. dalam hal pembiayaan diberikan dalam bentuk barang, maka barang yang diserahkan harus dinilai berdasarkan harga perolehan atau harga pasar wajar;

g. pembagian keuntungan dari pengelolaaan dana dinyatakan dalam bentuk nisbah yang disepakati; ${ }^{12}$

\footnotetext{
${ }^{12}$ Mekanisme perhitungan bagi hasil ini terdiri dari dua sistem, yaitu:
}

a. Profit Sharing, adalah perhitungan bagi hasil didasarkan kepada hasil net dari total pendapatan setelah dikurangi dengan biaya-biaya yang dikeluarkan untuk memperoleh pendapatan tersebut.

b. Revenue Sharing, adalah perhitungan bagi hasil didasarkan kepada total seluruh pendapatan yang diterima sebelum dikurangi dengan biaya-biaya yang telah dikeluarkan untuk memperoleh pendapatan tersebut.

Berdasarkan Fatwa Dewan Syariah Nasional Nomor 15/DSN-MUI/IX/2000 tentang Prinsip Distribusi Hasil Usaha Dalam Lembaga Keuangan Syariah ditetapkan bahwa:

1. Pada dasarnya LKS boleh menggunakan prinsip bagi hasil (net revenue sharing) maupun bagi untung (profit sharing) dalam pembagian usaha dengan mitra nasabahnya

2. Dilihat dari segi kemaslahatan (al-aslah), saat ini pembagian hasil usaha sebaliknya digunakan bagi hasil (net revenue sharing)

3. Penetapan prinsip pembagian hasil usaha yang dipilih harus disepakati dalam akad. 
h. Bank menanggung seluruh risiko kerugian usaha yang dibiayai kecuali jika nasabah melakukan kecurangan, lalai, atau menyalahi perjanjian yang mengakibatkan kerugian usaha;

i. nisbah bagi hasil yang disepakati tidak dapat diubah sepanjang jangka waktu investasi, kecuali atas dasar kesepakatan para pihak dan tidak berlaku surut;

j. nisbah bagi hasil dapat ditetapkan secara berjenjang (tiering) yang besarnya berbeda-beda berdasarkan kesepakatan pada awal Akad;

k. pembagian keuntungan dilakukan dengan menggunakan metode bagi untung dan rugi (profit and loss sharing) atau metode bagi pendapatan (revenue sharing);

1. pembagian keuntungan berdasarkan hasil usaha dari mudharib sesuai dengan laporan hasil usaha dari usaha mudharib;

m. dalam hal nasabah ikut menyertakan modal dalam kegiatan usaha yang dibiayai Bank, maka berlaku ketentuan;

i. nasabah bertindak sebagai mitra usaha dan mudharib;

ii. atas keuntungan yang dihasilkan dari kegiatan usaha yang dibiayai tersebut, maka nasabah mengambil bagian keuntungan dari porsi modalnya, sisa keuntungan dibagi sesuai kesepakatan antara Bank dan nasabah;

n. pengembalian pembiayaan dilakukan pada akhir periode Akad untuk pembiayaan dengan jangka waktu sampai dengan satu tahun atau dilakukan secara angsuran berdasarkan aliran kas masuk (cash in flow) usaha nasabah; dan

o. Bank dapat meminta jaminan atau agunan untuk mengantisipasi risiko apabila nasabah tidak dapat memenuhi kewajiban sebagaimana dimuat dalam Akad karena kelalaian dan/atau kecurangan.

Pada pembiayaan mudharabah bilamana kerugian dikarenakan dari risiko karakter buruk dari nasabah (character risk) misalnya nasabah lalai dan/atau melanggar persyaratan-persyaratan perjanjian mudharabah maka pemilik dana (shahibul maal/bank) tidak perlu menanggung kerugian seperti ini. Maka mudharib harus menanggung kerugian mudharabah sebesar bagian kelalaiannya 
sebagai sanksi dan tanggung jawabnya. Untuk menghindari moral hazard dari pihak mudharib yang lalai atau menyalahi kontrak maka pemilik dana (shahibul maal) dibolehkan meminta jaminan tertentu kepada mudharib. Jaminan ini akan disita oleh shahibul maal jika ternyata timbul kerugian karena mudharib melakukan kesalahan. Jadi tujuan penggenaan jaminan dalam akad mudaharabah adalah untuk menghindari moral hazard dari nasabah (mudharib) bukan untuk mengamankan nilai investasi jika terjadi kerugian karena faktor risiko bisnis. Tegasnya bila kerugian yang timbul disebabkan karena faktor risiko bisnis, jaminan mudharib tidak dapat disita oleh shahibul maal. ${ }^{13}$ Karakter dari pembiayaan mudharabah dapat digambarkan dalam tabel sebagai berikut:

Tabel 2. Karakter Pembiayaan Mudharabah

\begin{tabular}{|l|l|}
\hline \multicolumn{1}{|c|}{ Keterangan } & \multicolumn{1}{c|}{ Mudharabah } \\
\hline Prinsip yang melandasi & $\begin{array}{l}\text { Pembiayaan tersebut berdasarkan prinsip bagi hasil } \\
\text { (profit and loss sharing principle) }\end{array}$ \\
\hline Bentuk & $\begin{array}{l}\text { Kerja sama suatu usaha antara bank syariah sebagai } \\
\text { pemilik modal (shahibul maal) dengan nasabah } \\
\text { sebagai pengelola modal (mudharib). }\end{array}$ \\
\hline Jenis Modal & Jenis modal dalam bentuk uang tunai. \\
\hline Penyertaan Modal & $\begin{array}{l}\text { Pada pembiayaan mudharabah, hanya pemilik } \\
\text { modal (shahibul maal) yang menyerahkan modalnya } \\
\text { kepada pengelola modal (mudharib). Dengan modal } \\
\text { tersebut, si pengelola (mudharib) akan melakukan } \\
\text { kegiatan guna mengelola modal tersebut. }\end{array}$ \\
\hline Keuntungan & $\begin{array}{l}\text { Keuntungan tersebut dibagi berdasarkan kesepakatan } \\
\text { (nisbah bagi hasil) }\end{array}$ \\
\hline Kerugian & $\begin{array}{l}\text { Apabila terjadi kerugian maka akan ditanggung oleh } \\
\text { si pemilik modal (shahibul maal) dengan catatan } \\
\text { kerugian tersebut bukan karena kesengajaan dari } \\
\text { pihak pengelola modal (mudharib), sedangkan } \\
\text { pengelola modal rugi waktu, tenaga dan pikiran. } \\
\text { Sedangkan kerugian apabila disebabkan oleh } \\
\text { kelalaian dari pengelola modal (mudharib) maka } \\
\text { pengelola modal yang harus menanggung kerugian } \\
\text { tersebut. }\end{array}$ \\
\hline
\end{tabular}

${ }^{13}$ Adiwarman Karim, Bank Islam: Analisis Fiqih dan Keuangan, (Jakarta: RajaGrafindo Persada, 2007), hal. 209. 
Berdasarkan fatwa DSN Nomor 07/DSN-MUI/IV/2000 Tentang Pembiayaan Mudharabah (Qiradh) pada prinsipnya dalam pembiayaan mudharabah maupun pembiayaan musyarakah tidak ada jaminan, namun untuk menghindari terjadinya penyimpangan, LKS dapat meminta jaminan. Jaminan ini hanya dapat dicairkan apabila mudharib terbukti melakukan pelanggaran terhadap hal-hal yang telah disepakati bersama dalam akad. ${ }^{14}$ Persyaratan minimum dalam akad pembiayaan mudharabah yang diterapkan oleh perbankan syariah adalah sebagai berikut: ${ }^{15}$

a. menggunakan judul/kata' mudharabah (syarat akad)

b. menyebutkan hari dan tanggal akad dilakukan (syarat akad)

c. menyebutkan pihak yang bertransaksi dan/atau yang mewakilinya (rukun akad)

d. menetapkan bank sebagai pemilik dana atau shahibul maal dan nasabah sebagai pengelola dana atau mudharib (rukun akad)

e. mencantumkan nisbah bagi hasil yang disepakati bagi masing-masing pihak (rukun akad)

f. menetapkan jenis usaha yang akan dilakukan oleh nasabah (syarat akad)

g. menyebutkan bahwa kerugian ditanggung oleh bank apabila tidak disebabkan pelanggaran akad dan bertindak melebihi kapasitas (syarat akad)

h. menetapkan sanksi bagi nasabah apabila lalai membayar bagi hasil pada waktunya (kesepakatan)

i. menetapkan kesepakatan apabila terjadi force majeure (kesepakatan)

j. menetapkan jaminan dari pihak ketiga apabila diperlukan (kesepakatan)

k. menetapkan sanksi-sanksi apabila diperlukan (kesepakatan)

1. menetapkan Badan Arbitrase Syariah sebagai tempat penyelesaian apabila terjadi sengketa (kesepakatan)

\footnotetext{
${ }^{14}$ Dewan Syariah Nasional Majelis Ulama Indonesia, Himpunan Fatwa Dewan Syariah Nasional MUI, (Jakarta:Gaung Persada Press,2006), hal. 39 dan 52.

${ }^{15}$ Ascarya, Akad dan Produk Bank Syariah, ( Jakarta: RajaGrafindo Persada, 2007), hal. 66.
} 
Sebagai contoh akad pembiayaan mudharabah dari salah satu bank syariah X dengan klausula sebagai berikut: ${ }^{16}$

- Klausul tentang definisi:

a. Mudharabah adalah suatu bentuk kontrak kerja sama antara Bank sebagai shahibul maal/pemilik dana yang atas dasar kepercayaan menyerahkan dana sebagai modal, untuk dikelola oleh Nasabah sebagai mudharib sekaligus mitra usaha Bank yang bertanggung jawab melaksanakan/menjalankan usaha dengan dasar pembagian keuntungan terhadap hasil yang diperoleh sesuai kesepakatan dari menjalankan usaha tersebut tanpa harus membuat badan hukum. Akad kerja sama Mudharabah ini bersifat kontraktual, yang dapat menciptakan atau menimbulkan kewajiban bersama untuk melakukan pengendalian usaha bersaha (joint control), pengendalian bersama operasi (jointly controlled operation) dan pengendalian bersama asset (jointly controlled assets) dan mengatur mengenai hak, kewajiban dan tanggung jawab para pihak terhadap partisipasi finansial para pihak atau penyertaan modal, tanggung jawab pengendalian dan pengelolaan aktivitas operasional, cara pembagian hasil, pendapatan, beban atau hasil usaha, jangka waktu kerja sama dan kewajiban untuk menyampaikan laporan keuangan dan sisa hasil usaha. Hak dan kewajiban para pihak akan ditetapkan berdasarkan kesepakatan di antara para pihak, sebagaimana termaktub dalam pasal-pasal di dalam akad ini.

b. Nisbah adalah : Bagian dari hasil pendapatan/keuntungan yang menjadi hak NASABAH dan BANK yang ditetapkan berdasarkan kesepakatan antara NASABAH dengan BANK.

c. Bagi hasil atau syirkah adalah : Pembagian atas pendapatan/keuntungan antara NASABAH dan BANK yang ditetapkan berdasarkan kesepakatan antara NASABAH dengan BANK.

\footnotetext{
${ }^{16}$ Trisadini Prasastinah Usanti, et.al., Op. Cit., hal. 121.
} 
d. Pendapatan / Keuntungan Operasional adalah : pendapatan operasional yang diperoleh dari hasil usaha yang dijalankan NASABAH dengan menggunakan modal yang disediakan oleh BANK dan NASABAH setelah dikurangi biaya-biaya langsung yang dikeluarkan untuk memperoleh pendapatan tersebut, belum termasuk biaya-biaya tidak langsung yang dikeluarkan dalam mendukung kegiatan operasional usaha (overhead).

e. Pendapatan Bersih adalah : pendapatan yang diperoleh dari hasil usaha yang dijalankan NASABAH dengan menggunakan modal secara patungan dari yang disediakan oleh BANK dan NASABAH setelah dikurangi biayabiaya langsung yang dikeluarkan untuk memperoleh pendapatan tersebut serta biaya-biaya tidak langsung yang dikeluarkan dalam mendukung kegiatan operasional usaha (overhead) sebelum bagi hasil dan pajak-pajak.

f. Cedera Janji adalah : peristiwa atau peristiwa-peristiwa sebagaimana yang tercantum dalam Pasal .... Akad ini yang menyebabkan BANK dapat menghentikan seluruh atau sebagian Piutangnya, serta menagih dengan seketika dan sekaligus jumlah kewajiban NASABAH kepada BANK sebelum Jangka Waktu Akad ini berakhir.

\section{- Klausul tentang hak dan kewajiban para pihak dalam pengelolaan usaha} dan aset usaha:

1. Atas usaha yang menggunakan modal secara patungan dari yang disediakan oleh BANK dan NASABAH, NASABAH bertanggungjawab penuh terhadap jalannya operasional serta berwenang penuh mengendalikan sendiri aktivitas usaha, namun Bank berhak dan diberi kuasa untuk melakukan kontrol atau pengawasan sewaktu-waktu terhadap jalannya usaha tersebut.

2. Bank dan Nasabah secara bersama-sama berhak untuk mengambil bagiannya atas keuntungan sesuai dengan besarnya porsi bagi hasil yang telah disepakati dalam Akad ini.

3. Nasabah tidak bertanggung jawab terhadap seluruh kerugian usaha, kecuali terhadap hal-hal yang dilakukan menyimpang dari ketentuan dan 
kebijakan yang telah ditetapkan atau disepakati, seperti penyelewengan, spekulasi, monopoli, gharar, salah urus (mis-manajemen) dan pelanggaran sebagaimana yang dinyatakan dalam Pasal ... Akad ini, baik yang dilakukan Nasabah dengan sengaja atau tidak disengaja.

4. Apabila ternyata Nasabah menyimpang dan terjadi penyelewengan atas Akad ini, maka Bank berhak mengambil alih pengelolaan usaha, aset keuangan dan aset lainnya untuk diperhitungkan sebagai pembayaran utang Nasabah.

Pada klausul di atas menunjukkan karakter dari akad mudharabah, bahwa bank dan nasabah melakukan kegiatan kerjasama dalam bentuk modal dan kerja. Nasabah bertindak sebagai mudharib yang menjalankan kegiatan operasional dan bank syariah sebagai pemilik modal. Bank syariah dan nasabah berhak atas bagian keuntungan sesuai dengan porsi bagi hasil. Dalam hal tanggung jawab, nasabah tidak bertanggung jawab atas kerugian kecuali terhadap hal-hal yang dilakukan menyimpang dari ketentuan dan kebijakan yang telah ditetapkan atau disepakati, seperti penyelewengan, spekulasi, monopoli, gharar, salah urus (mis-manajemen) dan pelanggaran yang dinyatakan dalam akad, baik yang dilakukan nasabah dengan sengaja atau tidak disengaja.

\section{- Klausul tentang jumlah pembiayaan dan penggunaannya}

BANK berjanji dan dengan ini mengikatkan diri untuk menyediakan dana Pembiayaan kepada NASABAH sebagai modal sampai sejumlah Rp....................Penggunaan atas penyediaan dana dari Bank dilakukan secara bertahap ataupun sekaligus sesuai dengan kebutuhan dan permintaan Nasabah, yang akan digunakan oleh Nasabah khusus untuk membiayai usaha

\section{- Klausul tentang kesepakatan bagi hasil}

a. NASABAH dan BANK sepakat, dan dengan ini mengikatkan diri satu terhadap yang lain, bahwa Nisbah dari masing-masing pihak adalah :

$\%$ dari pendapatan/keuntungan untuk NASABAH;

.$\%$ dari pendapatan/keuntungan untuk BANK- 
b. NASABAH dan BANK juga sepakat, dan dengan ini saling mengikatkan diri satu terhadap yang lain, bahwa pelaksanaan Bagi Hasil (Syirkah) akan dilakukan pada tiap-tiap

c. BANK berjanji dan dengan ini mengikatkan diri untuk menanggung kerugian yang timbul dalam pelaksanaan Akad ini, kecuali apabila kerugian tersebut terjadi karena ketidakjujuran, kelalaian dan/atau pelanggaran yang dilakukan NASABAH terhadap ketentuan-ketentuan yang diatur dalam Pasal .... dan .... Akad ini.

d. BANK baru akan menerima dan mengakui terjadinya kerugian tersebut, apabila BANK atau kuasanya telah menerima dan memeriksa/menilai kembali segala perhitungan yang dibuat dan disampaikan oleh NASABAH kepada BANK, dan BANK telah menyerahkan hasil penilaiannya tersebut secara tertulis kepada NASABAH

e. NASABAH dan BANK berjanji dan dengan ini saling mengikatkan diri satu terhadap yang lain, bahwa BANK hanya akan menanggung segala kerugian secara proporsional, maksimum sebesar utang yang diberikan kepada NASABAH tersebut pada Pasal.....

Pada klausul di atas menunjukkan karakter dari mudharabah, yaitu adanya kesepakatan tentang nisbah bagi hasil bagi kedua belah pihak, dan ketentuan bahwa bank syariah sebagai shahibul maal akan menanggung kerugian kecuali apabila kerugian tersebut diakibatkan dari kelalaian nasabah sebagai mudharib. Prinsip kehati-hatian diterapkan oleh bank syariah dalam akad pembiayaan mudharabah, hal ini dituangkan dalam beberapa klausul. Bank syariah harus mematuhi prinsip kehati-hatian sebagai pertanggung jawaban atas pengelolaan dana dari nasabah simpanan dan nasabah investasi. Perwujudan prinsip kehatihatian nampak pada klausul tentang jaminan, klausul tentang pernyataan dan pengakuan nasabah, klausul tentang pelanggaran-pelanggaran, klausul tentang pengawasan dan pemeriksaan dan klausul tentang asuransi yaitu sebagai berikut:

a. NASABAH berjanji dan dengan ini mengikatkan diri, untuk menyerahkan perhitungan usaha yang dibiayai dari dana Bank berdasarkan Akad ini, secara 
periodik pada tiap-tiap bulan, selambat-lambatnya pada hari ke lima (5) bulan berikutnya.

b. BANK berjanji dan dengan ini mengikatkan diri untuk melakukan penilaian kembali atas perhitungan usaha yang diajukan oleh NASABAH, selambatlambatnya pada hari ke ...... sesudah BANK menerima perhitungan usaha tersebut yang disertai data dan bukti-bukti lengkap dari NASABAH.

c. Apabila sampai hari ke ......, BANK tidak menyerahkan kembali hasil penilaian tersebut kepada NASABAH, maka BANK dianggap secara sah telah menerima dan mengakui perhitungan yang dibuat oleh NASABAH.

\section{- Klausul tentang jaminan}

Sehubungan dengan fasilitas dana yang ditempatkan oleh Bank kepada Nasabah berdasarkan Akad ini, Nasabah berjanji dan dengan ini mengikatkan diri untuk :

a. Mengembalikan seluruh jumlah dana berikut bagian dari pendapatan/keuntungan Bank sesuai dengan Nisbah pada saat jatuh tempo sebagaimana ditetapkan pada Berita Acara yang dilekatkan pada dan karenanya yang menyangkut Nasabah maupun usahanya.

b. Melakukan pembayaran atas semua tagihan dari Pihak Ketiga melalui rekening Nasabah di Bank.

c. Membebaskan seluruh harta kekayaan milik Nasabah dari beban penjaminan terhadap pihak lain, kecuali penjaminan bagi kepentingan Bank berdasarkan Akad ini.

d. Mengelola dan menyelenggarakan pembukuan atas seluruh dana secara jujur dan benar dengan itikad baik dalam pembukuan tersendiri

e. Menyerahkan kepada Bank perhitungan usahanya yang dananya difasilitasi oleh Bank sebagaimana ditetapkan dalam Pasal ... Akad ini.

f. menyerahkan kepada Bank, setiap dokumen, bahan-bahan dan atau keterangan-keterangan yang diminta Bank kepada Nasabah.

g. menjalankan usahanya menurut ketentuan-ketentuan, atau tidak menyimpang atau bertentangan dengan prinsip-prinsip Syariah 
Untuk menjamin tertibnya pembayaran kembali/pelunasan utang mudharabah, maka PENJAMIN berjanji dan dengan ini mengikatkan diri untuk menyerahkan agunan/jaminan kepada Bank dan membuat perikatan jaminan kepada Bank sesuai dengan peraturan perundang-undangan yang berlaku, yang merupakan bagian yang tidak terpisahkan dari Akad ini, yaitu agunan/jaminan yang berupa:.

\section{- Klausul tentang pernyataan dan pengakuan nasabah}

NASABAH mengijinkan Bank pada saat ini dan untuk masa-masa selama berlangsungnya Akad, untuk memasuki tempat usaha dan tempat-tempat lainnya yang berkaitan dengan usaha NASABAH, mengadakan pemeriksaan terhdap pembukuan, catatan-catatan, transaksi, dan/atau kegiatan lainnya yang berkaitan dengan usaha berdasarkan Akad ini, baik langsung maupun tidak langsung.

\section{- Klausul tentang cidera janji}

Menyimpang dari ketentuan dalam Pasal ... Akad ini, BANK berhak untuk menuntut/menagih pembayaran dari NASABAH dan/atau siapa pun juga yang memperoleh hak darinya, atas sebagian atau seluruh jumlah kewajiban NASABAH kepada BANK berdasarkan Akad ini, untuk dibayar dengan seketika dan sekaligus, tanpa diperlukan adanya surat pemberitahuan, surat teguran, atau surat lainnya, apabila terjadi salah satu hal atau peristiwa tersebut di bawah ini :

a. NASABAH tidak melaksanakan pembayaran atas kewajibannya kepada BANK sesuai dengan saat yang ditetapkan dalam Pasal ... dan/atau Pasal ... Akad ini ;

b. dokumen, surat-surat bukti kepemilikan atau hak lainnya atau barang-barang yang dijadikan jaminan, dan/atau pernyataan pengakuan sebagaimana tersebut pada Pasal ... Akad ini ternyata palsu atau tidak benar isinya ; ----------

c. NASABAH melakukan perbuatan yang melanggar atau bertentangan dengan salah satu hal yang ditentukan dalam Pasal ... dan/atau Pasal .... Akad ini;-----

d. sebahagian atau seluruh harta kekayaan NASABAH disita oleh pengadilan atau pihak yang berwajib ; 
e. NASABAH berkelakuan sebagai pemboros, pemabuk, ditaruh di bawah pengampuan, dalam keadaan insolvensi, dinyatakan pailit, atau dilikuidasi;---

- Klausul tentang pelanggaran yang dilakukan oleh nasabah sebagai mudharib

NASABAH dianggap telah melanggar syarat-syarat Akad ini bila terbukti NASABAH melakukan salah satu atau lebih dari perbuatan-perbuatan sebagai berikut :

a. menggunakan pembiayaan yang diberikan BANK di luar tujuan atau rencana kerja yang telah mendapatkan persetujuan tertulis dari BANK;

b. melakukan pengalihan usahanya dengan cara apa pun, termasuk dan tidak terbatas pada melakukan penggabungan, konsolidasi, dan/atau akuisisi dengan pihak lain.

c. menjalankan usahanya tidak sesuai dengan ketentuan teknis yang diharuskan oleh BANK ;

d. melakukan pendaftaran untuk memohon dinyatakan pailit oleh pengadilan;

b. lalai tidak memenuhi kewajibannya terhadap Bank ;

c. lalai tidak memenuhi kewajibannya terhadap Piahk lain yang dapat mengganggu kelancaran usaha.

d. menolak atau menghalang-halangi BANK dalam melakukan pengawasan dan/atau pemeriksaan sebagaimana diatur dalam Pasal .... Akad ini.

\section{- Klausul tentang pengawasan dan pemeriksaan}

Atas kesepakatan kedua pihak, BANK atau Kuasanya berhak untuk melakukan pengawasan dan pemeriksaan atas pembukuan dan jalannya pengelolaan usaha yang mendapat fasilitas pembiayaan dari BANK berdasarkan Akad ini, serta halhal lain yang berkaitan langsung atau tidak langsung dengannya, termasuk dan tidak terbatas pada membuat photo copy / salinannya. 


\section{- Klausul tentang asuransi}

NASABAH berjanji dan dengan ini mengikatkan diri untuk menutup asuransi berdasar Syari'ah atas bebannya terhadap seluruh barang yang menjadi jaminan atas Pembiayaan berdasar Akad ini, pada perusahaan asuransi yang ditunjuk oleh BANK, dengan menunjuk dan menetapkan BANK sebagai pihak yang berhak menerima pembayaran claim asuransi tersebut (bankers clause).

Klausula yang termuat dalam akad mudharabah sebagaimana di paparkan di atas secara umum telah menunjukkan karakter dari akad mudharabah, akan tetapi akadnya terdapat klausul tentang pembayaran kembali ternyata memuat kata utang sebagaimana dalam klausul di bawah ini:

\section{- Klausul tentang pembayaran kembali ${ }^{17}$}

Apabila NASABAH membayar kembali atau melunasi hutang ${ }^{\mathbf{1 8}}$ yang difasilitasi oleh BANK lebih awal dari waktu yang diperjanjikan, maka tidak berarti pembayaran tersebut akan menghapuskan atau mengurangi bagian dari keuntungan yang menjadi hak BANK sebagaimana yang telah ditetapkan dalam Akad ini.

Dalam klausul di atas disebutkan istilah utang dalam akad mudharabah, padahal dalam uraian sebelumnya disebutkan bahwa karakter dari pembiayaan mudharabah yang berdasarkan bagi hasil adalah akad kerjasama antara shahibul maal dengan mudharib, bukan akad utang piutang (pinjam meminjam). Hubungan hukum yang terbentuk adalah hubungan kerjasama usaha antara shahibul maal dengan mudharib, apabila terjadi kerugian yang bukan disebabkan oleh kecurangan atau kelalaian dari mudharib maka tidak mucul utang yang menjadi kewajiban dari mudharib untuk mengembalikannya, sebaliknya apabila kerugian tersebut disebabkan oleh mudharib maka mudharib harus bertanggung jawab atas

\footnotetext{
${ }^{17}$ Ibid, hal. 157. Pada akad Pembiayaan Mudharabah pada bank syariah yang lainnya,yaitu bank syariah Y tidak menggunakan konsep utang dalam klausulnya

18 Istilah yang tepat berdasarkan undang-undang, yaitu Pasal 1 angka 6 Undang-Undang Nomor 37 Tahun 2004 tentang Kepailitan dan Penundaan Kewajiban Pembayaran Utang, Pasal 1 angka 7 Undang-Undang Nomor 42 Tahun 1999 tentang Jaminan Fidusia adalah utang bukan hutang.
} 
kerugian tersebut karena mudharib telah mengkhianati amanah yang telah diberikan oleh shahibul maal. oleh karena itu, bank syariah perlu lebih teliti dalam menuangkan konsep utang dalam klausul akad pembiayaan mudharabah.

Pelaku bank syariah X berdalih bahwa munculnya istilah utang dalam akad mudharabah dikarenakan dalam neraca bank, penyaluran dana dan penghimpunan dana oleh bank syariah dibukukan sebagai utang karena dana yang dipergunakan adalah sebagian besar adalah dana masyarakat, sehingga modal yang disalurkan pada pembiayaan dianggap utang maka harus terbayarkan. Pada Peraturan Bank Indonesia Nomor 7/13/PBI/2005 tentang Kewajiban Modal Minimum Bank Umum Berdasarkan Prinsip Syariah sebagaimana telah diubah dengan Peraturan Bank Indonesia Nomor 8/7/PBI/2006, bahwa bank syariah wajib menyediakan modal minimum sebesar $8 \%$ (delapan perseratus) dari aktiva tertimbang menurut risiko. Modal tersebut oleh bank syariah dipergunakan untuk membiayai infrastruktur misalnya pembangunan gedung bank syariah, penempatan ATM di kantor-kantor cabang.

Dalam fiqih muamalah ${ }^{19}$ akad dibedakan dalam berbagai penggolongan dilihat dari beberapa sudut pandang, salah satunya membagi akad dalam dua macam yaitu akad tijarah/mu'awadah dan akad tabarru'. ${ }^{20}$ Akad tijarah/mu'awadah adalah akad yang bertujuan untuk mendapatkan keuntungan, atau akad yang menyangkut transaksi bisnis dengan motif untuk memperoleh laba (profit oriented). Contoh akad tijarah adalah akad yang berdasarkan prinsip jualbeli (murabaha, salam dan istishna), akad yang berdasarkan prinsip bagi hasil (mudharabah dan musyarakah), akad yang berdasarkan prinsip sewa-menyewa (ijarah dan ijarah wa iqtina/ ijarah muntahia bittamlik).

Akad tabarru' adalah jenis akad yang berkaitan dengan transaksi nonprofit. Transaksi ini pada hakikatnya bukan transaksi bisnis yang mencari keuntungan. Akad yang menitik beratkan pada prinsip tolong menolong tidak mengutamakan

19 Hukum-hukum yang berkaitan dengan tindakan manusia dalam persoalan-persoalan keduniaan, misalnya dalam persoalan jual beli, utang piutang, kerjasama dagang, perserikatan, kerjasama dalam penggarapan tanah dan sewa menyewa, sebagaimana dikutip dari Abdul Rahman Ghazaly,et.al, Fiqh Muamalat, (Jakarta: Kencana Prenada Media, 2010), hal. 4.

${ }^{20}$ Syamsul Anwar, Hukum Perjanjian Syariah, (Jakarta: RajaGrafindo, 2007), hal.83. 
mencari untung. Melakukan kebaikan yang mengharapkan balasan dari Allah SWT semata. Contoh akad tabarru' adalah akad qardh, rahn, hiwalah,wakalah, kafalah, wadiah dan lain-lain. Akad Qardh adalah akad pinjam meminjam sebagaimana diatur dalam Pada Peraturan Bank Indonesia Nomor 7/46/PBI/2005 Tentang Akad Penghimpunan dan Menyalurkan Dana Bagi Bank Yang Melaksanakan Kegiatan Usaha Berdasarkan Prinsip Syariah, Qardh diartikan sebagai pinjam meminjam dana tanpa imbalan dengan kewajiban pihak peminjam mengembalikan pokok pinjaman secara sekaligus atau cicilan dalam waktu tertentu. Karakteristik dari akad $A l$ Qardh adalah tanpa adanya imbalan keuntungan.

Pinjam meminjam merupakan akad yang menitikberatkan pada sikap tolong menolong atau ta'awun dan dengan demikian maka balasannya akan berupa pahala dari Allah swt. Salah satu prinsip yang mendasari akad adalah prinsip ta'awun (saling menguntungkan) setiap akad yang dilakukan harus bersifat saling menguntungkan semua pihak yang berakad. Suatu akad harus memperhatikan kebersamaan. Dalam surat Al Maidah ayat 2 menerangkan: “ ... Hendaklah kamu tolong menolong dalam kebaikan dan takwa dan janganlah kamu tolong menolong untuk berbuat dosa dan permusuhan”. Ayat ini menerangkan bahwa tolong menolong dalam ketaqwaan merupakan salah satu faktor penegak agama karena saling tolong menolong akan menciptakan rasa saling memiliki di antara umat sehingga akan lebih mengikat persaudaraan. Sedangkan dalam hadits nabi dikatakan bahwa ariah (barang pinjaman) adalah barang yang wajib dikembalikan ( HR. Abu Daud dan At-Tirmizi). Kaidah fiqh: "Setiap utang piutang yang mendatangkan manfaat (bagi yang berpiutang, muqridh) adalah riba." 21

Nampak bahwa akad pembiayaan mudharabah yang diterapkan oleh bank syariah X belum secara kaffah menunjukkan karakter dari akad mudharabah. Hal ini tidak dapat dipungkiri sebagai lembaga intermediasi, bank syariah

\footnotetext{
21 Abd.Shomad dan Trisadini P.Usanti, "Asas-Asas Perikatan Islam dalam Akad Pembiayaan", Yuridika, Volume 24, No.3. September-Desember 2009, hal.214.
} 
berkewajiban untuk mematuhi prinsip kehati-hatian pada kegiatan usahanya, karena pada hakikatnya kepatuhan terhadap prinsip kehati-hatian adalah sebagai jaminan atas amanah yang sudah diberikan oleh nasabah. Oleh karena itu, untuk melindungi kepentingan dana nasabah maka bank syariah wajib memegang teguh prinsip kehati-hatian agar bank syariah dalam keadaan sehat, likuid, solvent dan profitable. $^{22}$

\section{PENUTUP}

Akad mudharabah adalah akad kerjasama antara dua pihak, yaitu pihak pertama (shahibul maal) menyediakan seluruh modal, sedangkan pihak lain (mudharib) menjadi pengelola, keuntungan usaha dibagi dalam bentuk prosentase (nisbah) sesuai kesepakatan, sedangkan apabila rugi ditanggung oleh pemilik modal selama kerugian itu bukan akibat kelalaian si pengelola, seandainya kerugian itu diakibatkan oleh kelalaian si pengelola maka si pengelola harus bertanggung jawab atas kerugian tersebut. Akan tetapi, pada akad mudharabah pada salah satu bank syariah terdapat konsep utang dalam klausul akadnya, seharusnya tidak menggunakan konsep utang dalam akad mudharabah mengingat karakter akadnya adalah akad kerjasama bukan akad utang piutang. Akan tetapi, pihak bank syariah beralasan bahwa dana yang dihimpun oleh bank dalam neraca dibukukan sebagai utang demikian juga pada penyaluran dana dalam neraca juga dibukukan sebagai utang. Oleh karena itu, dana yang dipergunakan dalam pembiayaan adalah dana nasabah penyimpan dana maka nasabah penerima fasilitas pembiayaan berkewajiban untuk mengembalikan modal yang sudah diterimanya sesuai dengan jangka waktu yang telah ditentukan.

${ }^{22}$ Trisadini Prasastinah Usanti, Prinsip Kehati-hatian Pada Transaksi Perbankan Syariah (Surabaya: Airlangga University Press,2013), hal.311 


\section{DAFTAR PUSTAKA}

Antonio,Muhammad Syafii, Bank Syariah : Suatu Pengenalan Umum, Jakarta:Tazkia Institute, 2000.

Anwar, Syamsul , Hukum Perjanjian Syariah, Jakarta: RajaGrafindo, 2007

Ascarya, Akad dan Produk Bank Syariah, Jakarta: RajaGrafindo Persada, 2007.

Bank Indonesia. "Data pembiayaan yang diberikan (PYD) dari data statistik Perbankan Syariah". [www.bi.go.id.]. Diakses pada Tanggal 20 Oktober 2013

Dewan Syariah Nasional Majelis Ulama Indonesia. Himpunan Fatwa Dewan Syariah Nasional MUI. Jakarta: Gaung Persada Press, 2006.

Dewan Syariah Nasional. Fatwa DSN Nomor 07/DSN-MUI/IV/2000 Tentang Pembiayaan Mudharabah (Qiradh)

Dewan Syariah Nasional. Fatwa Dewan Syariah Nasional Nomor 15/DSNMUI/IX/2000 tentang Prinsip Distribusi Hasil Usaha Dalam Lembaga Keuangan Syariah

Ghazaly, Abdul Rahman,et.al, Fiqh Muamalat,Jakarta: Kencana Prenada Media, 2010

Indonesia. Undang-Undang tentang Perbankan. UU Nomor 7 Tahun 1992. LN Tahun 1992 Nomor 31, TLN Nomor 3472.

Indonesia. UndangUndang-Undang tentang Perubahan Undang-Undang Nomor 7 Tahun 1992 Tentang Perbankan. UU 10 Tahun 1998. LN Tahun 1998 Nomor 182, TLN Nomor 3790.

Indonesia. UU tentang Jaminan Fidusia. UU Nomor 42 Tahun 1999. LN Tahun 1999 Nomor 168, TLN Nomor .

Indonesia. UU Undang-Undang tentang Kepailitan dan Penundaan Kewajiban Pembayaran Utang. UU Nomor 37 Tahun 2004. LN Tahun 2004 Nomor 131, TLN Nomor .

Indonesia. Undang-Undang tentang Perbankan Syariah. UU Nomor 21 Tahun 2008. LN Tahun 2008 Nomor 94, TLN .

Indonesia. Peraturan Bank Indonesia Nomor 7/13/PBI/2005 tentang Kewajiban Modal Minimum Bank Umum Berdasarkan Prinsip Syariah sebagaimana telah diubah dengan Peraturan Bank Indonesia Nomor 8/7/PBI/2006.

Indonesia. Peraturan Bank Indonesia Nomor 7/46/PBI/2005 tentang Akad penghimpunan Dana dan Penyaluran Dana Bagi Bank Yang Melaksanakan Kegiatan Usaha Berdasarkan Prinsip Syariah jo. Peraturan Bank Indonesia Nomor Peraturan Bank Indonesia Nomor 9/19/PBI/2007 tentang 
Pelaksanaan Prinsip Syariah Dalam Kegiatan Penghimpunan Dana dan Penyaluran Dana serta pelayanan Jasa Bank Syariah

Indonesia. Peraturan Bank Indonesia Nomor 12/13/PBI/2011 tentang Penilaian Kualitas Aktiva Bagi Bank Umum Syariah dan Unit Usaha Syariah

Karim, Adiwarman, Bank Islam: Analisis Fiqih dan Keuangan, Jakarta: RajaGrafindo Persada, 2007.

Saeed, Abdullah, Islamic Banking and Interest a Study of The Prohibition of riba and Contemporery Intrepretation, NEW YORK-KOLN:E.J BRIIL LEIDEN,1996.

Sjahdeini, Sutan Remy, Perbankan Islam dan Kedudukannya dalam Tata Hukum Perbankan Indonesia, Jakarta: Pustaka Utama Grafiti, 1999.

Shomad, Abd. dan Trisadini P.Usanti, " Asas-Asas Perikatan Islam dalam Akad Pembiayaan”, Yuridika, Volume 24, No.3. September-Desember, 2009

Tim Couterpart Bank Muamalat, Fiqh Muamalah Perbankan Syariah, hasil terjemahan dari Buku Al Fiqh Aal Islam wa Adillatuhu, karya Wahbah Zuhaili, Jakarta, 1999.

Usanti, Trisadini Prasastinah, Prinsip Kehati-hatian Pada Transaksi Perbankan Syariah Surabaya: Airlangga University Press,2013.

Usanti,Trisadini Prasastinah,et.al., Prinsip Keadilan dalam Transaksi Berdasarkan Bagi Hasil di Bank Syariah", Penelitian dibiayai oleh DIPA BOPTN Tahun Anggaran 2013 sesuai dengan Surat Keputusan Rektor Universitas Airlangga Tentang Kegiatan Penelitian Unggulan Perguruan Tinggi Nomor:8714/UN3/KR/2013 Tanggal 25 Juni 2013

Yahman dan Trisadini Prasastinah Usanti, Bunga Rampai Hukum Aktual Dalam Prespektif Hukum Bisnis Kontraktual Berimplikasi Pidana dan Perdata, Surabaya: Mitra Mandiri,2011.

Zulkifli,Sunarto, Panduan Praktis Transaksi Perbankan Syariah, Jakarta:Zikrul Hakim, 2003. 